Discussion Paper No. 15-082

\title{
Tax Competition in Europe - Europe in Competition with Other World Regions?
}

Frank Streif

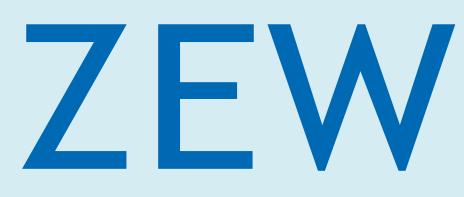

Zentrum für Europäische Wirtschaftsforschung $\mathrm{GmbH}$ Centre for European Economic Research 
Discussion Paper No. 15-082

\title{
Tax Competition in Europe - Europe in Competition with Other World Regions?
}

\author{
Frank Streif
}

Download this ZEW Discussion Paper from our ftp server:

http://ftp.zew.de/pub/zew-docs/dp/dp15082.pdf

Die Discussion Papers dienen einer möglichst schnellen Verbreitung von neueren Forschungsarbeiten des ZEW. Die Beiträge liegen in alleiniger Verantwortung der Autoren und stellen nicht notwendigerweise die Meinung des ZEW dar.

Discussion Papers are intended to make results of ZEW research promptly available to other economists in order to encourage discussion and suggestions for revisions. The authors are solely responsible for the contents which do not necessarily represent the opinion of the ZEW. 


\title{
Tax Competition in Europe -
}

\section{EUROPE IN COMPETITION WITH OTHER WORLD REGIONS?}

\author{
Frank Streif* \\ (ZEW Mannheim and University of Mannheim)
}

This version: 16 November 2015

\begin{abstract}
Corporate tax levels have fallen substantially in Europe during the last decades. A broad literature has identified tax competition as one reason for this decline in corporate tax levels. However, none of these studies explicitly asks the question whether tax competition within regions is different from tax competition across regions, e.g. due to global regionalism of foreign direct investments. This is a crucial question to answer in order to discuss the desirability of tax harmonization in a distinct region, for example, within the European Union. Therefore, the study aims to give hints on the question whether the decline in corporate tax levels in Europe is mainly driven by tax competition between EU member states or by pressure from other world regions. The results of this study, which makes use of tax reaction functions, indicate that there is evidence for tax competition within Europe, whereas there is no robust evidence that European countries compete with countries from other world regions.
\end{abstract}

JEL Classification Code: H2, H77, H87

Keywords: corporate taxes, tax competition, tax harmonization, Europe

*Address of correspondence: Frank Streif, Department for Corporate Taxation and Public Finance, ZEW Mannheim, L7 1, 68161 Mannheim, Germany, +49 6211235 398, streif@zew.de

The author would like to thank Zareh Asatryan, Benjamin Bittschi, Sebastian Blesse, Friedrich Heinemann, Thorsten Martin, Christoph Spengel, Robert Ullmann and Johannes Voget for valuable comments, as well as Julian Lutz and Anja Schulz for excellent research assistance. 


\section{Introduction}

Corporate tax levels have fallen substantially in Europe during the last decades. In Germany, the effective average tax rate (EATR) has fallen from $45.82 \%$ in 1990 to $28.40 \%$ in 2013. Figure 1 shows the development of the average EATRs for four world regions which are covered in this study (Latin America, Europe, Asia-Pacific and North America). The development of the corporate effective tax levels in Europe appears most remarkable. The average European EATR has fallen substantially from approximately 30\% in 1996 to approximately $20 \%$ in 2012 (see Figure 1). The downward trend in taxation levels in Europe is steady over time, however, the decline pre 2005 is more distinct than post 2005. Unlike other regions, the average EATR in Latin America has risen slightly over the period from 1996 to 2012. In North America and in the Asia-Pacific region the average EATR has fallen, however, less dramatically than in Europe. There is a broad literature which stipulates that the global decline in corporate tax levels is due to tax competition. However, none of these studies explicitly asks the question whether tax competition within regions is different from tax competition across regions. This is a crucial question to answer in order to discuss the desirability of tax harmonization in a distinct region, for example, in the European Union. Therefore, this study aims to answer the following question: Is the decline in corporate tax levels in Europe mainly driven by tax competition between EU member states or is it (also) due to pressure from other world regions?

The investigation of this question deserves special attention for at least the following reason: The desirability of tax harmonization within the EU is linked to the relationship of the EU with third countries and other world regions. In a globalized world, tax competition might not stop at the European border. Tax harmonization would possibly reduce tax pressure within Europe, however, the pressure from outside would not vanish if it exists. By harmonizing their tax systems, member states might lose their flexibility to react to tax changes in countries from other world regions. Schön (2003, p. 28) 
describes this as the member states putting themselves into a "straitjacket". On the other hand, Schön (2003) remarks that the existence of other economic areas could make harmonization within Europe even more necessary in order to reduce transaction and compliance cost within Europe, and make Europe as a whole, more competitive compared to other world regions. Due to pressure from outside Europe, the positive effects of tax competition (e.g. disciplining public budgets) would still apply in a harmonized system. Complementary to this reasoning, Sørensen (2004) sets up a general equilibrium model in which he distinguishes between global and regional tax coordination. He makes the point, that regional tax coordination might not be desirable when considering third countries. Therefore, the first contribution of this paper is, to analyze the extent of tax competition within Europe on the one hand, and between Europe and other world regions on the other hand.

Empirically, the paper follows the classical spatial econometrics approach applied in the public finance literature. I specify a dynamic panel data model, which is the second contribution of this paper to the international tax competition literature that has mostly applied static models thus far. The recent literature on local government interactions shows that applying the standard instruments in tax reaction functions, might not isolate possible common shocks or spatially correlated (unobservable) effects from the real effects of interest and can therefore overestimate the strength of strategic interactions (see, e.g. Baskaran, 2014, 2015; Isen, 2014; Lyytikäinen, 2012). In the analysis, I will carefully take these new insights into account when interpreting the results.

\section{Background and Literature}

\section{Foreign Direct Investment in the Context of Regional Economic Blocs}

There are reasons why tax competition between countries of the same regional bloc might be more intense than between countries of different regional blocs. ${ }^{1}$ If trade costs

$1 \quad$ Regional blocs can be distinct from each other for several reasons: Firstly, distance between countries of the same regional bloc is often smaller than across blocs. Secondly, cultural barriers within 
Figure 1: Development of Effective Average Tax Rates (EATRs)

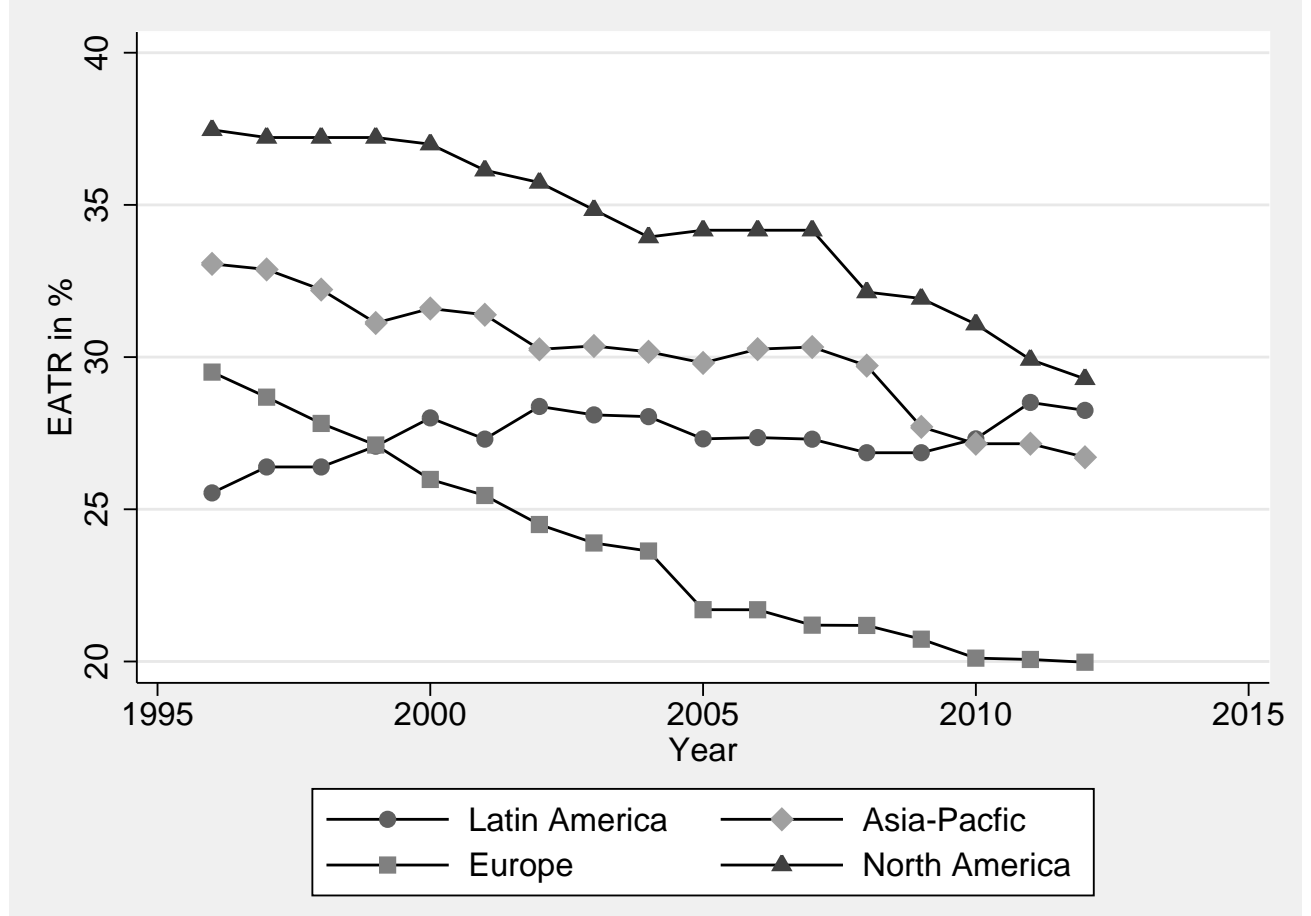

within the bloc are low, this may induce countries within the bloc to compete for FDI more strongly than with countries outside the bloc. This in turn can be reflected in the tax setting behavior of the governments when corporate taxes are not coordinated or harmonized. The FDI literature shows that a multinational firm from outside a region needs to decide to either produce (i) in each country of the region, (ii) produce in one country within the region and use that location as export-platform, or (iii) export its products from its home market (third country). Likewise, companies from within the region need to decide where to locate most efficiently. Decisive factors for this can be trade costs and barriers to FDI within and across regional blocs.

The effects of global regionalism and economic integration on the choice between exporting and FDI have been analyzed in theoretical papers: Motta and Norman (1996) emphasize the relevance and impact that regional blocs have on firms. They show that

a regional bloc are likely to be smaller and consumer preferences to be more similar. And thirdly, countries within a region are likely to have both bilateral trade treaties and free trade area agreements. Also see Motta and Norman (1996) for the term "regional bloc". 
economic integration within a bloc causes outside firms to invest in the regional bloc. Crucially, firms do not invest equally in each country of the bloc but make use of "intraregional export platform FDI, with the investing firm supplying the majority of the countries in the regional bloc by intra-regional export" (Motta and Norman, 1996, p. 775). In addition to this "third country" perspective, Motta and Norman (1996) point out that FDI activity of inside firms might actually decrease, since they will choose intraregional exports instead of dispersed FDI when intra-regional trade costs are sufficiently low. Both these effects intensify tax competition between countries within the regional bloc: Firstly, inside countries have an incentive to compete for the (additional) FDI attracted by the economically integrated area from third countries, and secondly, the less diversified within-bloc FDI makes inside countries compete more intensively for FDI than they would in less integrated areas. Analogous implications occur when considering the theoretical FDI papers from Rowthorn (1992), Motta (1992) and Smith (1987). ${ }^{2}$ This competition might be reflected in the tax setting behavior of states.

Closely related to the general term "regional bloc" are free-trade areas. In this context, Ekholm et al. (2007) analyze the possibility of export-platform foreign direct investment and show that a free trade area can give incentives to multinationals to invest in that area. Crucially, multinationals would only invest in one of the countries in the free-trade area, and serve the whole market within the free-trade area by exports. In line with the theoretical studies, there is strong empirical evidence that free-trade areas attract investments from third countries and that multinationals choose one country within the area as an export-platform; see, e.g. Ekholm et al. (2007) for US multinationals' investment in NAFTA and the $\mathrm{EU}^{3}$, Blonigen et al. (2007) for US multinationals' investment

2 Rowthorn (1992) analyzes intra-industry trade and investment under oligopoly and emphasizes the role of market size and trade barriers between countries. Motta (1992) and Smith (1987) model firms' choice between direct investment and exporting.

3 They show that US affiliates in free-trade areas (EU and NAFTA) mainly export within the freetrade area. The paper finds that it is not so much about countries' membership in NAFTA and the EU, respectively, but more about countries belonging to the same geographical area. They argue that this is likely due to "North American and European locations [constituting] relatively integrated markets independent of the formation of formal free-trade areas through NAFTA and the EU" (Ekholm et al., 2007, p. 789). 
in the EU, and Blomstrom and Kokko (1997) for investments in CUSFTA. These studies confirm empirically Motta and Norman's theory-based hypothesis of higher FDI inflows from third countries into regional blocs and less intra-bloc FDI.

With respect to Europe, there is reliable evidence that regional integration has affected FDI and trade flows within and into Europe. Pain (1997), for example, finds that U.K. direct investments into other EU countries have been stimulated by the internal market programme. Crucially, he also identifies some U.K. firms to have diverted their investments from the United States into the EU. This adds an additional aspect and provides micro-level evidence that regional economic blocs do not function independently to third countries. ${ }^{4}$ Similarly, Baltagi et al. (2008) argue that the European Agreements on trade liberalization did not only affect trade flows but also FDI. They emphasize the interdependence of allocation decisions and conclude that "a sizable stimulus of investment in one country or region eventually causes a reduction of investment in other countries or regions" (Baltagi et al., 2008, p. 195).

\section{Tax Competition}

There are two papers which explicitly draw the relationship between regional economic integration, FDI flows and tax interactions. Raff (2004) shows theoretically that FDI is likely to increase in an integrated region and that countries within that region might have an incentive to attract FDI from the rest of the world by a favorable tax environment. The setting reflects the real world where trade within geographical regional blocs is likely to be less costly than across regions, however, at the same time, tax policies within regions are hardly harmonized.

Redoano (2014) connects to this reasoning and is closely related to this paper as it also focuses on the European context. Her main hypothesis argues that "the lower cost of cross-border FDI between EU member countries, on the one hand, and the lack of tax harmonization programs between members, on the other hand, should cause EU countries to compete more intensively for FDI amongst themselves than with countries

\footnotetext{
$4 \quad$ Baldwin et al. (1995) also detect investment diversion in the European context.
} 
outside the EU" (Redoano, 2014, p. 354). Empirically, the hypothesis of more intense tax competition within the EU is confirmed on the basis of a Western European data set.

This paper goes one step further and analyzes how far tax competition within Europe and between Europe and the rest of the world differs. I closely relate to the empirical literature which attempts to identify strategic interactions among countries by using tax reaction functions. ${ }^{5}$ Devereux et al. (2008) analyse for 21 OECD countries if they compete with respect to their corporate taxes. They find compelling evidence for international tax competition in statutory tax rates. States also seem to interact with respect to the effective tax rates. Although evidence for this is weak. The study does not show whether the results are driven by certain country constellations, or country clusters and is therefore unable to address the research questions posed by this paper. Furthermore, Egger and Raff (2014) develop a theoretical model which allows for two dimensions of interactions, i.e. interaction in tax rates and tax bases. In their empirical contribution, they show that observed changes in countries' tax rates and bases are a consequence of increased regional trade integration.

In the European context, Crabbé (2013) shows by means of tax reaction functions that EU15 member states which are geographically close to the new Eastern European member states, react more strongly to the new member states' tax levels than more remote EU15 countries do. Similarly, Davies and Voget (2008) conclude that the extension of the EU has intensified tax competition. However, these studies do not answer the question whether EU states compete with other world regions. A recent study by Altshuler and Goodspeed (2015) is related to the research question of this paper, as it poses the question whether the US acts as a Stackelberg leader for the European countries. However, their

$\overline{5}$ Besides the empirical studies, the theoretical strand of the existing tax competition literature tries to identify conditions under which different possible consequences of tax competition occur (for example a race to the bottom); see, e.g. Zodrow and Mieszkowski (1986), Gordon (1986), Razin and Sadka (1991) and Zodrow (2006). Other papers determine theoretically, in which dimension (e.g. statutory tax rates) countries compete with each other; see, e.g. Haufler and Schjelderup (2000), Devereux et al. (2008), Fuest and Hemmelgarn (2005) and Becker and Fuest (2011).

Descriptive studies have shown how various tax parameters have developed over the last centuries. See, e.g. Elschner et al. (2011), Devereux et al. (2002), Gorter and de Mooij (2001) and Devereux (2007). 
measure for taxation, corporate tax revenues divided by GDP, is vulnerable to cyclical effects within and/or across regions and only an indirect measure for effective average tax rates. A further study by Overesch and Rincke (2011) also finds strong (weak) evidence for competition in statutory tax rates (effective average tax rates) in Europe. Given that the data only consists of European countries, the paper cannot address the questions raised in this paper, i.e. how far tax competition within Europe and between Europe and the rest of the world differs.

\section{Empirical Methodology}

The tax competition literature referred to in section 2 makes use of tax reaction functions to detect strategic interaction among countries. Tax reaction functions assume that a country's level of corporate taxes is a function of the level of corporate taxes in the other countries. Theoretically, it is possible that country $i$ reacts differently to all other countries. However, most of the literature that uses tax reaction functions makes the assumption that country $i$ reacts to the average level of corporate taxes of all other countries. This assumption is mainly due to data limitations, since in the case of country specific response possibilities the number of coefficients to be estimated would equal the number of countries. That would not be a feasible estimation strategy. The literature has solved this problem by building an average of the tax levels of all other countries and making an ex-ante choice about the weighting of the elements in this average. Thus, the variable of interest is the weighted average tax level of all other countries (excluding country $i$ ) which is called "spatial lag". In this case, only one coefficient is estimated which then captures how country $i$ reacts to the average tax rate of all other countries. ${ }^{6}$ In my paper, I use specifications which allow for more than one average in order to detect country constellations and regions which drive the results.

$6 \quad$ E.g., Devereux et al. (2008) use one average when testing whether or not there is international tax competition. 
With respect to the weighting scheme, there have been different approaches in the literature, for example theory-based weights like GDP or trade flows. However, these weighting variables might be related to the corporate tax levels themselves and therefore be endogenous. Recently, Klemm and Parys (2012) have used uniform weights and Redoano (2014) distance weights which circumvent the additional endogeneity problem which other weighting schemes cause. I choose to use both uniform and distance weights in all specifications which constitutes a first robustness test for the results. ${ }^{7}$

Besides the average taxes of the other countries, the tax level of a country might also be determined by its own tax level in the previous period, since countries face adjustment costs when changing their effective average tax rate (EATR). Consequently, the EATR adjusts only gradually when exogenous factors change and does not jump into a new equilibrium instantly. Therefore, I specify a dynamic model with the lagged dependent variable as an explanatory variable. Dynamic models have been applied in similar circumstances before, for example by Cassette et al. (2012) in a local taxation context or by Foucault et al. (2008) in the context of public spending interactions in French municipalities, but not yet so much by studies testing worldwide tax competition. ${ }^{8}$ The results of this paper show that a government's choice on its country's EATR is highly path-dependent.

In the specification, the EATR of country $i=1, \ldots, N$ at time $t=1, \ldots, T$ is denoted by $\tau_{i t}$ where $\mathrm{N}$ is the number of countries and $\mathrm{T}$ represents the number of time periods. The tax reaction function of state $i$ can be written as (baseline specification):

$$
\tau_{i t}=\gamma \tau_{i t-1}+\delta \sum_{j \neq i}^{N} w_{i j} \tau_{j t}+\mathbf{X}_{i t} \boldsymbol{\beta}+\rho t_{r}+\alpha_{i}+\varepsilon_{i t}
$$

\footnotetext{
$7 \quad$ As distance measure I use simple geodesic distances provided by the research institute CEPII. I use the inverse distance as weight and row normalize the weights to one.

8 Devereux et al. (2008) and Davies and Voget (2008) apply static models.
} 
where $\alpha_{i}$ is a country-specific fixed effect, $\rho t_{r}$ represents a regional linear time trend and $\varepsilon_{i t}$ is an error term. ${ }^{9}$

The EATR of country $i$ is a function of the average EATR of the other countries, which is represented by the spatial lag term $\sum_{j \neq i}^{N} w_{i j} \tau_{j t}$ where $w_{i j}$ is the weight with which the EATR of country $\mathrm{j}\left(\tau_{j t}\right)$ goes into the average EATR of the other countries. $X_{i t}$ represents a vector of time varying control variables that are expected to influence the EATR and represent sensible controls in order to make the variable of interest (spatial lag) uncorrelated with the error term.

The dynamic nature of the specification imposes (internal) validity problems. In an ordinary OLS regression, the country-fixed effect in the error term causes the lagged dependent variable to be upward biased. The problem of endogeneity does not vanish when using fixed- or random-effects OLS estimations (Nickell, 1981). Dynamic panel data estimators tackle this problem by constructing first differenced regression equations. The error term and the first differenced lagged dependent variable are still correlated in such specifications, however, this can be circumvented by instrumenting the difference of the lagged dependent variable by lags of its levels (or differences).

With tax reaction functions, there is a second major endogeneity concern: the spatial lag is endogenous by assumption because tax reaction functions explicitly accommodate that countries interact with each other. Thus, the error term of country $i$ is correlated with the spatial lag because country $i$ itself has an influence on the tax setting behavior of the other countries. Previous literature deals with this problem by instrumenting the spatial lag by the (weighted) average of the covariates of all other countries (i.e. the countries contained in the spatial lag). These covariates qualify as instruments as they are

$9 \quad$ In the main specifications I do not include time dummies due to their high multicollinearity with the spatial lag (see, e.g. Elhorst, 2010; Klemm and Parys, 2012; Devereux et al., 2008). However, I use regional linear time trends for four world regions to allow for unobserved factors to vary over time. 
uncorrelated with the error term of country i but are correlated with the other countries' tax levels. ${ }^{10}$

Both endogeneity problems described above can be tackled efficiently by system GMM estimation as proposed by Blundell and Bond (1998) and recently applied in the context of tax reaction functions by Klemm and Parys (2012). ${ }^{11}$ System GMM uses lagged levels for instrumenting current differences and lagged differences for instrumenting current levels. Beside the benefit of using internal instruments, it is also possible to include additional (exogenous) variables as instruments which are not part of the second stage regression specification. This is useful for the setting in this paper in order to use the covariates of the other countries to instrument the spatial lag. ${ }^{12}$ In the international tax setting context at hand, system GMM has the additional benefit that it can deal with the only modest adjustments in effective tax levels in some countries by taking into account interactions in levels as well as in first differences.

With respect to the assumptions of system GMM, the Hansen J test of overidentifying restrictions allows to check whether the instruments are correlated with the residuals. The null hypothesis that there is no correlation between instruments and residuals cannot be rejected for any of the regressions conducted in the analysis. Furthermore, the Arellano and Bond (1991) statistics on the first and second order autocorrelation of the firstdifferenced residuals is employed. The second order correlation is relevant since the model is specified in first differences and the autocorrelation in levels needs to be checked. ${ }^{13}$

$\overline{10}$ The covariates of the other countries are averaged by the same weighting scheme which applies to the spatial lag. This approach is also chosen by, for example, Devereux et al. (2008), Davies and Voget (2008), Klemm and Parys (2012) and Redoano (2014).

11 Furthermore, Madariaga and Poncet (2007) apply this method in the context of FDI spillovers and Foucault et al. (2008) in the context of public spending interactions. Similarly, Cassette et al. (2012) use difference GMM for analyzing local tax competition.

12 I restrict the number of instruments by only using one lag in order to keep the number of instruments manageable as suggested by Roodman (2009, p. 124). This lag specification applies to all regressions in the paper. The robust option is used in order to produce results robust to heteroskedasticity and "arbitrary patterns of autocorrelation" within countries Roodman (2009, p. 123).

13 The null hypothesis of no autocorrelation cannot be rejected at the $5 \%$ significance level for the baseline results (Table 1) except for one regression. 


\section{Data}

\section{Country coverage}

The (balanced) panel data set of this paper covers 44 countries over the period 1996 to 2012. The data set consists of four world regions, namely Europe, North America, Latin America and the Asia-Pacific region. Naturally, the European region makes up for the majority of the 44 countries. ${ }^{14}$ For competition in FDI the effective average tax rate (EATR) is the relevant measure as argued by Devereux and Griffith (1998, p. 337) and Devereux and Griffith (2003). Besides statutory tax rates, EATRs also take into account depreciation methods for assets and the valuation method for inventories. This is important to measure when governments do not only interact with respect to statutory tax rates, but also use favorable depreciation schemes to become more attractive for FDI. $^{15}$

\section{Development of Effective Average Tax Rates}

The dynamics related to the EU enlargement in 2004 deserve special attention. The data shows that the average EATR in Europe has decreased significantly from 1996 to 2012 (Figure 1 in section 1 and Table A8 in the appendix). More precisely, the mean EATR of the EU28 has fallen from $29.5 \%$ in 1996 to $20.4 \%$ in 2012 . However, there are substantial differences between the old (EU15) and the new member states (EU13). Throughout time, the mean EATR of the EU15 was higher than the one of the EU13. Additionally, the dynamics of the EATRs were different between the two groups. The new member states lowered their mean EATR drastically until 2004 (year of entry into the EU for the EU10). Afterwards, they kept decreasing their tax rates, however, the downward pace became considerably slower. In contrast, the old member states lowered their mean EATR during the pre-enlargement period less drastically but then slightly increased their downward movement after the enlargement. Empirical studies show that

\footnotetext{
14 Table A6 and A7 in the appendix provide information on the countries covered.

15 Section 7.2.1 in the appendix explains the data sources and computation assumptions.
} 
the EU extension might have played a causal role for the observed dynamics (Davies and Voget, 2008; Crabbé, 2013). I will take this into account in the analysis

\section{Control Variables}

For the empirical analysis, I merge the EATR data with a set of time varying control variables $X_{i t}$. Government consumption expenditure (Gov't Consumption $\left.{ }_{i t}\right)$ is supposed to reflect the need of a government (or society) to generate tax revenues in order to serve its preferences for the provision of public goods and redistributive policies. In addition, I include demographic variables which might have an effect on the tax setting behavior of states, i.e. the share of people living in urban areas $\left(\operatorname{Urban}_{i t}\right)$ and the share of dependents as percent of the working-age population (Dependency $y_{i t}$ ).

To capture the openness of an economy, I borrow a measure used by Overesch and Rincke (2011); it is computed by summing up a country's imports and exports and dividing it by its GDP (Openness $s_{i t}$ ). The effect of this openness measure is ambiguous, since, first, the (un-)openness of an economy shows if a government tries to attract foreign FDI altogether and, second, high trade volumes can also indicate that multinationals find it more attractive to serve the market by imports rather than by direct investments as argued in section 2. To control for the size of an economy and thus for its possible market power, the GDP $\left(G D P_{i t}\right)$ of the respective country is included. Table A5 in the appendix provides descriptive statistics for these covariates and the EATR.

\section{Results}

\section{$5.1 \quad$ Main Results}

\section{Global Tax Competition}

The first specification reflects the presented baseline regression in section 3 , i.e. the EATR of country $i$ is explained by the weighted average EATR of all other countries. The results in column 1 (uniform weighting) and 2 (distance weighting) of Table 1 show 
no evidence for international tax competition. The single spatial lag is neither significant for the uniform weights nor for the distance weights. This contributes to an already ambiguous literature in which some papers find evidence for international tax competition in a single spatial lag framework using an international data set (e.g., Devereux et al., 2008) and some papers do not (Davies and Voget, 2008, p. 26 columns 2 and 3). The assumption that states adjust their tax parameters only gradually towards a new equilibrium is confirmed by the high and significant coefficient of the lagged dependent variable in Table 1.

The main result, namely that the spatial lag is not positively significant, raises the questions if this also holds when I refine my approach and look at more regional tax competition. It is conceivable that the last result is not so much a sign of non-existence of tax competition between countries but more a sign for tax competition taking place rather within regional blocs than across regions as argued in the theoretical part of this paper. This can be due to export-platform strategies which are more likely to play a role within regions than across regions.

\section{Regional Tax Competition}

In the following, I take regional tax competition aspects into consideration by regressing the EATR of country $i$ on the weighted average EATR of the other countries in the region of country i. The analysis provides no evidence for the existence of general tax competition within regions (column 3 and 4 of Table 1). Both the spatial lag of the uniform and the distance specification are not significant at the $10 \%$ significance level. This result is relatively remarkable given that European countries make up the majority of the sample. However, when dropping the non-European observations and reducing the sample size, the spatial lag turns significantly positive in the uniform specification (column 5 and 6 in Table 1). This indication of tax competition within Europe is confirmed in the subsequent specifications (column 7-10 in Table 1) and is in line with the literature. However, the details are different: Overesch and Rincke (2011) find evidence for tax competition within 


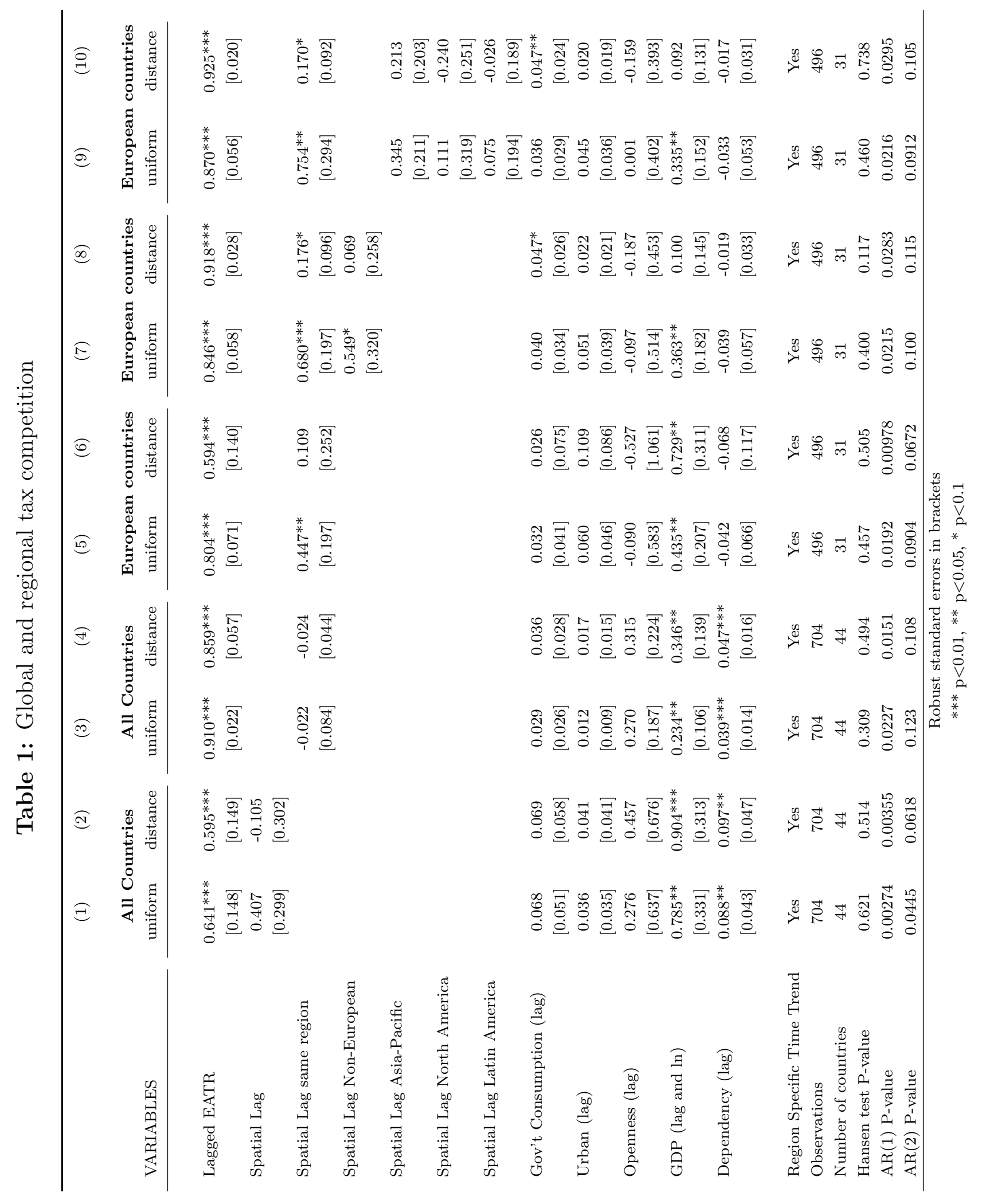


Europe, however, only with respect to statutory tax rates. ${ }^{16}$ Davies and Voget (2008) also find evidence for tax competition within Europe when looking at the EATR. They use a static model whereas this study confirms the result by means of a dynamic model. Redoano (2014) also shows that there is European tax competition.

\section{Tax Competition in Europe - Europe in Competition with other World Regions?}

For tax policy in Europe, the question of European tax competition is important. For the desirability and the design of tax coordination or harmonization, however, it is also very relevant whether or not there is evidence that European countries react to effective tax levels of non-European countries. The answer to this question plays a significant role in the discussion on the advantages and disadvantages of tax harmonization as argued in the introduction. Full harmonization of corporate taxation in the EU could eventually put member states into a "straitjacket" which would prevent them from flexibly reacting to tax pressure from other world regions if such pressure exists (Schön, 2003, p. 28). ${ }^{17}$

The regressions in column 7 and 8 of Table 1 address this question. The EATR of the European countries is regressed on the (weighted) average EATR of the other European countries and the (weighted) average EATR of all non-European countries. Consistent with the previous result, the European spatial lag ("Spatial lag same region") is now even more positive and statistically significant for both types of weighting schemes. However, evidence for the relevance of the effective tax levels of the non-European countries is weak. The spatial lag for the non-European countries is only significant at the $10 \%$ significance level for the uniform weights and not significant at all for the distance weights. When refining this approach and splitting the non-European spatial lag into its regional components, evidence for tax pressure from other world regions on the European countries

\footnotetext{
16 They also test for competition in EMTRs and EATRs but find no robust evidence in these cases. Potentially, this could be due to the fact that they address the endogeneity of their dynamic specification by using OLS fixed effects which does not fully solve the endogeneity problem caused by the lagged dependent variable.

17 For a thorough discussion on this and related arguments please see Schön (2003).
} 
vanishes altogether. Neither the spatial lag for North America, Latin America nor the Asian-Pacific region shows any statistically significant effect. This result can be seen as a confirmation of the FDI papers on economic integration and export-platform FDI. They suggest that economic integration leads to tougher competition for FDI within the integrated area whereas it is theoretically not clear if competition between regional blocs intensifies. In general, the result is in line with Redoano (2014, p. 354) who stipulates that "EU countries compete more intensively for FDI amongst themselves than with countries outside the EU". Overall, it can be cautionary concluded that there does not seem to be evidence for tax pressure on European countries from other world regions. Instead, the fall in effective tax rates in Europe can be attributed to tax competition within Europe.

\subsection{Robustness}

Throughout the paper I apply both uniform and distance weights. Both circumvent any additional endogeneity problem which might occur when using weights like trade or FDI flows. The uniform weighting scheme is useful in this paper, since I run intra-regional regressions where distance is likely to play a smaller role than between different regional blocs (Klemm and Parys, 2012). The results presented do not show much sensitivity to the respective weighting scheme. All main conclusions hold for both regression specifications. In the following, I run additional robustness checks with respect to time effects and the construction of regional blocs. Additionally, the results are extended to European tax competition considerations.

\section{Construction of Regional Blocs}

The FDI literature analyzing export-platform strategies and countries' competition for FDI looks at both "free-trade areas" and "regional blocs", the latter being a more general concept of an integrated economic area. Free-trade areas often constitute an integrated economic area before the formalization through a free-trade agreement as argued by 
Ekholm et al. (2007). Therefore, the empirical analysis of this paper rather focuses on geographically and economically integrated regions than explicitly considering free-trade areas.

In the case of Mexico, the question arises if it is more integrated with Latin American (through Mercosur) or with North America (through NAFTA). Therefore, I conduct a sensitivity analysis which affiliates Mexico to North America when analyzing whether there is tax competition within regions. Table A1 in the appendix confirms that general evidence for tax competition within regions cannot be detected.

With respect to European countries, the paper does not strictly focus on EU membership in the main analysis. Even if a country is not member of the EU or only joined the EU at a later stage, the European economies show a substantial degree of integration due to privileged free-trade relationships. Consequently, I also include Switzerland, Norway and Turkey in the main analysis which have well-established economic relationships with the EU (e.g. through EFTA in the case of Switzerland and Norway). For robustness I run regressions that rather focus on the EU instead of Europe by excluding the latter three countries. The main results remain valid (Column 3-8 in Table A1), however, statistical significance for tax competition within Europe becomes slightly weaker.

\section{Time Effects}

The main specifications do not include time dummies, since they would almost be identical to the spatial lag. The time dummy would represent the average tax level in a given year. The spatial lag, in turn, also represents the (weighted) average tax level in a given year, except the tax level of the country of the dependent variable. Due to the high multicollinearity between the spatial lag and the time dummy, the spatial lag cannot be interpreted meaningfully in this case (see, e.g. Elhorst, 2010; Klemm and Parys, 2012; Devereux et al., 2008). This is especially true with uniform weighting. The problem might be less severe with distance weights. Therefore, I experiment with time dummies for the distance regressions and present them in Table A2. Again, there is no evidence for tax pressure from other world regions on Europe. 


\section{European Considerations}

The main results indicate that there is no general tax competition across or within regions. Tax competition seems to be a relatively specific European phenomenon. The descriptive sketch in section 4 and the studies by Davies and Voget (2008) and Crabbé (2013) show that the EU enlargement process might have contributed to interaction dynamics. Crabbé (2013) emphasizes the new member states' impact on the old member states which are located eastward. Similarly, Davies and Voget (2008) argue that tax competition within the EU member states is stronger and that the EU enlargement has intensified tax competition in Europe. When I run the regressions only on the EU15 member states (Table A3, column 3-4), I find no significant effects and, in a way, the findings of Crabbé (2013) and Davies and Voget (2008) are confirmed. Furthermore, EU28 states seem to react in particular to the new EU13 member states (Table A3, column 5-6), which confirms the important role the EU13 played in the dynamics of European corporate taxes.

\section{Discussion and Conclusions}

Overall, there is a substantial amount of literature which analyses strategic tax interactions between countries. Especially in the context of the European Union, it has been argued that member states' sensitivity to each other has led to lower effective corporate taxes. The integrated economic area in the EU has arguably promoted this development. The paper supports this, and at the same time, finds no evidence for the existence of regional tax competition in other world regions, for example in Asia or in Latin America. Furthermore, there is no evidence for tax competition across regions, and more specifically, for the influence of non-European corporate taxes on tax levels of EU member states.

In general, the implied causalities of the results in classical spatial econometrics frameworks have to be interpreted cautiously, since it is questionable that the exogeneity condition for the instruments holds. Recently, Gibbons and Overman (2012), Lyytikäinen 
(2012), Baskaran (2014), and Isen (2014) show that the strength of detected strategic interactions can be severely overestimated, when using the traditional spatial lag approach. These papers analyze interactions at the local level and make use of policy interventions and institutional variations within and/or across borders, when instrumenting the spatial lag. In light of the detected weaknesses of the standard spatial econometrics method, the result of no inter-regional tax competition gains additional credibility. Although I apply a method which tends to overestimate strategic interactions, only interactions within Europe are found. Overall, only moderately robust evidence for international tax interactions has been provided by the literature thus far, which perhaps has to be treated with caution, given the new methodical insights form the studies on local jurisdictions.

Considering the results of this study and the former literature, the desirability of corporate tax harmonization in the EU remains questionable:

Firstly, the descriptives and empirics do not make a convincing case for an outright harmonization of corporate taxes. It is unclear how strong strategic interactions among EU member states really are and whether or not Europe experiences a "race-to-the-bottom" with respect to effective tax rates. In addition, there is no indication for inefficiently low levels of public good provision caused by tax competition. The annual report on taxation trends in the European Union illustrates that tax revenues in percent of GDP exhibit a rather unclear trend despite the fall in statutory tax rates; in the long term perspective, corporate tax revenues have even increased (European Commission, 2014, p. 31). ${ }^{18}$

Secondly, from a normative perspective, it is unresolved if complete tax harmonization is the first best solution to tax competition. On the one hand, the results indicate that tax competition with other regions is unlikely to be very strong, which would make regional tax harmonization a valid option (Sørensen, 2004). On the other hand, the economic advantages of harmonization need to be traded off against the disadvantages coming from political economy factors, like governments being Leviathans, or the benefits of tax harmonization being unevenly distributed due to asymmetries across member states

18 Simmons (2006, p. 24) also observes that corporate tax revenues have increased in the EU15 over the last decades both with respect to total tax revenues and GDP. 
(Baskaran and Lopes da Fonseca, 2014; Cardarelli et al., 2002; Itaya et al., 2008; Osterloh and Heinemann, 2013).

Also, there are alternative solutions to tax competition which are milder than complete tax harmonization: Firstly, Baskaran and Lopes da Fonseca (2014) argue in favor of intergovernmental transfers between EU member states, in order to smooth adverse effects from tax competition. This perspective is currently opened up, given the discussions on the advancement of the European Union into a federal state with more integrated budgets and equalization schemes. ${ }^{19}$ And, secondly, instead of complete corporate tax harmonization it appears natural to consider more well-dosed harmonization steps, like a Common Consolidated Corporate Tax Base (CCCTB) or a Common Corporate Tax Base (CCTB) which has been put forward recently in the Action Plan of the EU Commission. ${ }^{20}$ Both systems would greatly reduce compliance costs for corporations and make the EU as a whole more competitive and attractive compared to other world regions. This could be a feasible path to attract mobile capital and keep corporate tax revenues up (Keuschnigg et al., 2014, p. 18). At the same time, member states could still set their own tax rates and preserve some degree of tax autonomy.

19 See for example an interview by the French minister of finance: http://international. sueddeutsche.de/post/128026249890/refondons-leurope

20 The full Draft Council Directive on a Common Consolidated Corporate Tax Base (CCCTB) from 2011 is available for download under: http://ec.europa.eu/taxation_customs/resources/ documents/taxation/company_tax/common_tax_base/com_2011_121_en.pdf

Information to the recent CCCTB re-launch can be found under: http://europa.eu/rapid/ press-release_MEMO-15-5174_de.htm

Please also see the Bolkestein Report (European Commission, 2001) and Spengel et al. (2012) for an economic analysis of company taxation in the internal market and the CCTB, respectively, as well as Fuest (2008) for a critical analysis of the EU Commission's original Draft Council Directive. 


\section{References}

Altshuler, R. and T. J. Goodspeed (2015). Follow the Leader? Evidence on European and US Tax Competition. Public Finance Review 43(4), 485-504.

Arellano, M. and S. Bond (1991). Some Tests of Specification for Panel Data: Monte Carlo Evidence and an Application to Employment Equations. Review of Economic Studies 58(2), 277-97.

Baldwin, R. E., R. Forslid, and J. Haaland (1995). Investment Creation and Investment Diversion: Simulation Analysis of the Single Market Programme. Working Paper 5364, National Bureau of Economic Research.

Baltagi, B. H., P. Egger, and M. Pfaffermayr (2008). Estimating Regional Trade Agreement Effects on FDI in an Interdependent World. Journal of Econometrics 145(1-2), $194-208$.

Baskaran, T. (2014). Identifying Local Tax Mimicking with Administrative Borders and a Policy Reform. Journal of Public Economics 118, 41-51.

Baskaran, T. (2015). Tax Mimicking in the Short- and Long-Run: Evidence from German Reunification. Discussion Papers 230, University of Goettingen.

Baskaran, T. and M. Lopes da Fonseca (2014). The Economics and Empirics of Tax Competition: A Survey and Lessons for the EU. Erasmus Law Review 7(1).

Becker, J. and C. Fuest (2011). Optimal Tax Policy when Firms are Internationally Mobile. International Tax and Public Finance 18(5), 580-604.

Blomstrom, M. and A. Kokko (1997). Regional Integration and Foreign Direct Investment. NBER Working Papers 6019, National Bureau of Economic Research, Inc. 
Blonigen, B. A., R. B. Davies, G. R. Waddell, and H. T. Naughton (2007). FDI in Space: Spatial Autoregressive Relationships in Foreign Direct Investment. European Economic Review 51(5), $1303-1325$.

Blundell, R. and S. Bond (1998). Initial Conditions and Moment Restrictions in Dynamic Panel Data Models. Journal of Econometrics 87(1), 115-143.

Cardarelli, R., E. Taugourdeau, and J.-P. Vidal (2002). A Repeated Interactions Model of Tax Competition. Journal of Public Economic Theory 4(1), 19-38.

Cassette, A., E. D. Porto, and D. Foremny (2012). Strategic Fiscal Interaction Across Borders: Evidence from French and German Local Governments along the Rhine Valley. Journal of Urban Economics 72(1), 17 - 30.

Crabbé, K. (2013). Are Your Firm's Taxes Set in Warsaw? Spatial Tax Competition in Europe. FinanzArchiv: Public Finance Analysis 69(3), 317-337.

Crabbé, K. and H. Vandenbussche (2008). Are Your Taxes Set in Warsaw? Spatial Tax Competition in Europe. Open Access publications from Katholieke Universiteit Leuven urn:hdl:123456789/386123, Katholieke Universiteit Leuven.

Davies, R. B. and J. Voget (2008). Tax Competition in an Expanding European Union. Working Papers 0830, Oxford University Centre for Business Taxation.

Devereux, M. P. (2007). Developments in the Taxation of Corporate Profit in the OECD Since 1965: Rates, Bases and Revenues. Working Papers 0704, Oxford University Centre for Business Taxation.

Devereux, M. P. and R. Griffith (1998). Taxes and the Location of Production: Evidence from a Panel of US Multinationals. Journal of Public Economics 68(3), 335-367.

Devereux, M. P. and R. Griffith (2003). Evaluating Tax Policy for Location Decisions. International Tax and Public Finance 10(2), 107-26. 
Devereux, M. P., R. Griffith, and A. Klemm (2002). Corporate Income Tax Reforms and International Tax Competition. Economic Policy 17(35), 449-495.

Devereux, M. P., B. Lockwood, and M. Redoano (2008). Do Countries Compete Over Corporate Tax Rates? Journal of Public Economics 92(5-6), 1210-1235.

Devereux, M. P. and M. Pearson (1995). European Tax Harmonisation and Production Efficiency. European Economic Review 39(9), 1657 - 1681.

Egger, P. and H. Raff (2014). Tax Rate and Tax Base Competition for Foreign Direct Investment. International Tax and Public Finance (First Online), 1-34.

Ekholm, K., R. Forslid, and J. R. Markusen (2007). Export-Platform Foreign Direct Investment. Journal of the European Economic Association 5(4), 776-795.

Elhorst, J. (2010). Spatial Panel Data Models. In M. M. Fischer and A. Getis (Eds.), Handbook of Applied Spatial Analysis, pp. 377-407. Springer Berlin Heidelberg.

Elschner, C., J. H. Heckemeyer, and C. Spengel (2011). Besteuerungsprinzipien und Effektive Unternehmenssteuerbelastungen in der Europäischen Union: Regelt sich die EU-weite Steuerharmonisierung von Selbst? Perspektiven der Wirtschaftspolitik 12(1), $47-71$.

European Commission (2001). Company Taxation in the Internal Market. Technical Report COM (2001) 582, Brussels.

European Commission (2014). Taxation Trends in the European Union: 2014 Edition. Taxation trends 2014, Directorate General Taxation and Customs Union, European Commission.

Foucault, M., T. Madies, and S. Paty (2008). Public Spending Interactions and Local Politics. Empirical Evidence from French Municipalities. Public Choice 137(1), 57-80. 
Fuest, C. (2008). The European Commission's Proposal for a Common Consolidated Corporate Tax Base. Working Papers 0823, Oxford University Centre for Business Taxation.

Fuest, C. and T. Hemmelgarn (2005). Corporate Tax Policy, Foreign Firm Ownership and Thin Capitalization. Regional Science and Urban Economics 35(5), 508-526.

Gibbons, S. and H. G. Overman (2012). Mostly Pointless Spatial Econometrics? Journal of Regional Science 52(2), 172-191.

Gordon, R. H. (1986). Taxation of Investment and Savings in a World Economy. The American Economic Review 76(5), pp. 1086-1102.

Gorter, J. and R. de Mooij (2001). Capital Income Taxation in Europe; Trends and Trade-Offs. CPB Special Publication 30, CPB Netherlands Bureau for Economic Policy Analysis.

Haufler, A. and G. Schjelderup (2000). Corporate Tax Systems and Cross Country Profit Shifting. Oxford Economic Papers 52(2), 306-25.

Isen, A. (2014). Do Local Government Fiscal Spillovers Exist? Evidence from Counties, Municipalities, and School Districts. Journal of Public Economics 110, 57-73.

Itaya, J.-i., M. Okamura, and C. Yamaguchi (2008). Are Regional Asymmetries Detrimental to Tax Coordination in a Repeated Game Setting? Journal of Public Economics 92(12), 2403-2411.

Keuschnigg, C., S. Loretz, and H. Winner (2014). Tax Competition and Tax Coordination in the European Union: A Survey. Economics Working Paper Series 1427, University of St. Gallen, School of Economics and Political Science.

Klemm, A. and S. Parys (2012). Empirical Evidence on the Effects of Tax Incentives. International Tax and Public Finance 19(3), 393-423. 
Lyytikäinen, T. (2012). Tax Competition Among Local Governments: Evidence from a Property Tax Reform in Finland. Journal of Public Economics 96(7-8), 584-595.

Madariaga, N. and S. Poncet (2007). FDI in Chinese Cities: Spillovers and Impact on Growth. The World Economy 30(5), 837-862.

Motta, M. (1992). Multinational Firms and the Tariff-Jumping Argument: A Game Theoretic Analysis with some Unconventional Conclusions. European Economic Review $36(8), 1557-1571$.

Motta, M. and G. Norman (1996). Does Economic Integration Cause Foreign Direct Investment? International Economic Review 37(4), 757-83.

Nickell, S. J. (1981). Biases in Dynamic Models with Fixed Effects. Econometrica 49(6), $1417-26$.

Osterloh, S. and F. Heinemann (2013). The Political Economy of Corporate Tax Harmonization - Why Do European Politicians (Dis)Like Minimum Tax Rates? European Journal of Political Economy 29, 18 - 37.

Overesch, M. and J. Rincke (2011). What Drives Corporate Tax Rates Down? A Reassessment of Globalization, Tax Competition, and Dynamic Adjustment to Shocks. Scandinavian Journal of Economics 113(3), 579-602.

Pain, N. (1997). Continental Drift: European Integration and the Location of U.K. Foreign Direct Investment. The Manchester School 65(S), 94-117.

Raff, H. (2004). Preferential Trade Agreements and Tax Competition for Foreign Direct Investment. Journal of Public Economics 88(12), 2745 - 2763.

Razin, A. and E. Sadka (1991). International Tax Competition and Gains from Tax Harmonization. Economics Letters 37(1), 69 - 76.

Redoano, M. (2014). Tax Competition Among European Countries. Does the EU Matter? European Journal of Political Economy 34, 353-371. 
Roodman, D. (2009). How to Do Xtabond2: An Introduction to Difference and System GMM in Stata. Stata Journal 9(1), 86-136.

Rowthorn, R. (1992). Intra-Industry Trade And Investment Under Oligopoly: The Role of the Market Size. Economic Journal 102(411), 402 - 414.

Schön, W. (2003). Tax Competition in Europe - General Report. W. Schön (Ed.), Tax Competition in Europe Amsterdam: IBFD, 1-42.

Simmons, R. S. (2006). Does Recent Empirical Evidence Support the Existence of International Corporate Tax Competition? Journal of International Accounting, Auditing and Taxation 15(1), $16-31$.

Smith, A. (1987). Strategic Investment, Multinational Corporations and Trade Policy. European Economic Review 31(1-2), 89-96.

Sørensen, P. B. (2004). International Tax Coordination: Regionalism versus Globalism. Journal of Public Economics 88(6), 1187-1214.

Spengel, C., M. Ortmann-Babel, B. Zinn, and S. Matenaer (2012). A Common Corporate Tax Base for Europe: An Impact Assessment of the Draft Council Directive on a CC(C)TB. World Tax Journal, October, 185-221.

Zodrow, G. (2006). Capital Mobility and Source-Based Taxation of Capital Income in Small Open Economies. International Tax and Public Finance 13(2), 269-294.

Zodrow, G. R. and P. Mieszkowski (1986). Pigou, Tiebout, Property Taxation, and the Underprovision of Local Public Goods. Journal of Urban Economics 19(3), 356 - 370. 


\section{Appendix}

\subsection{Robustness Results}

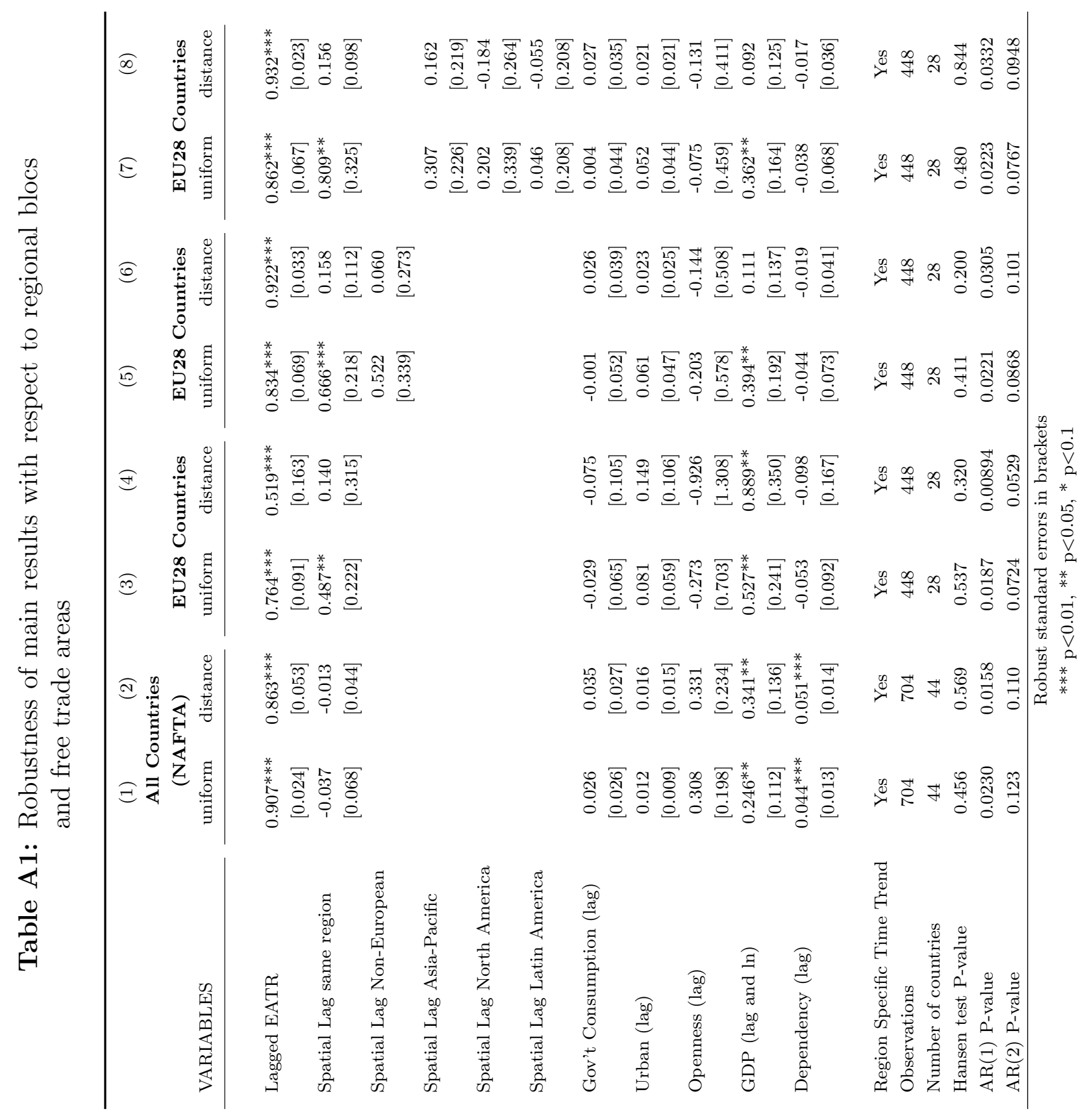




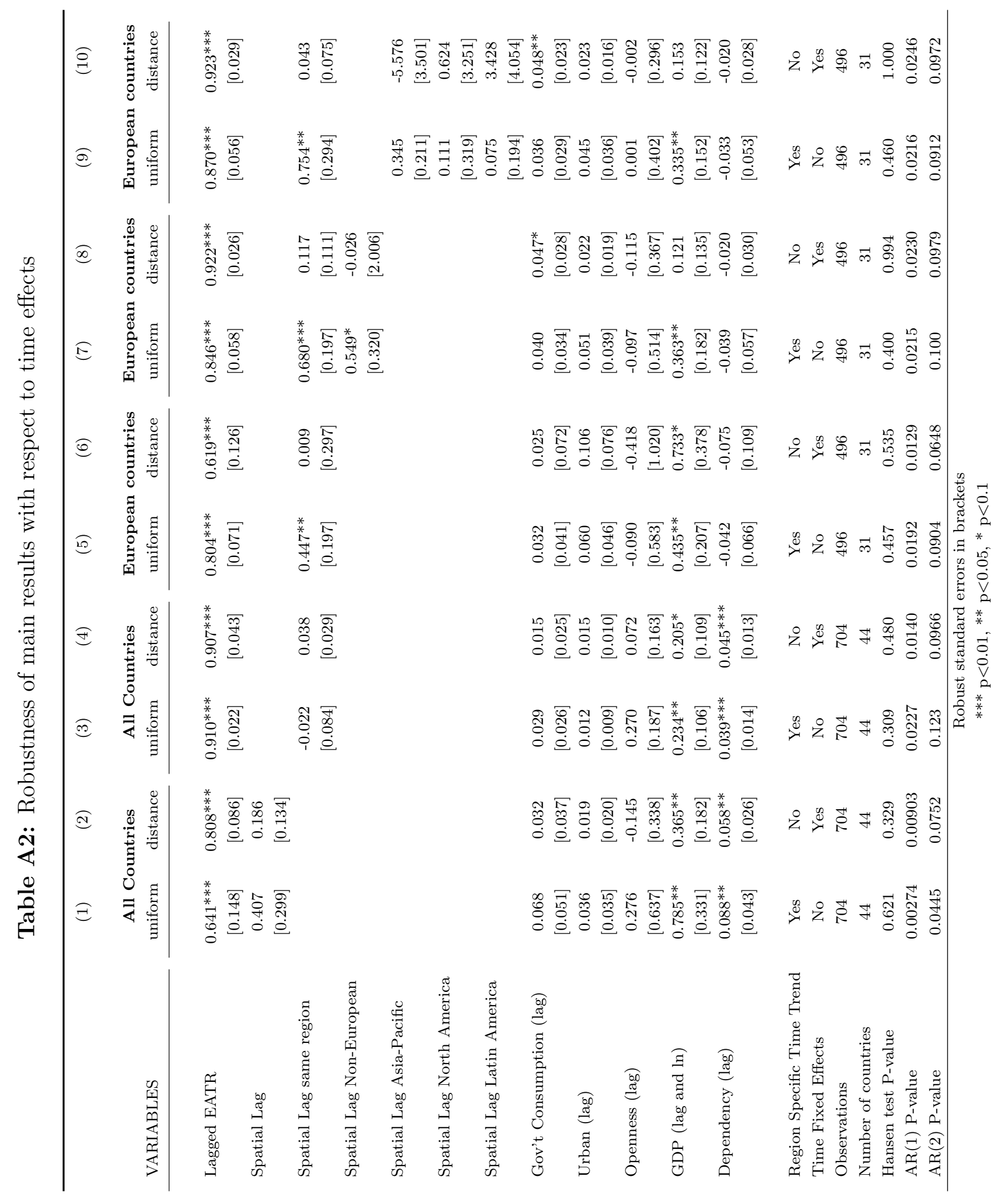




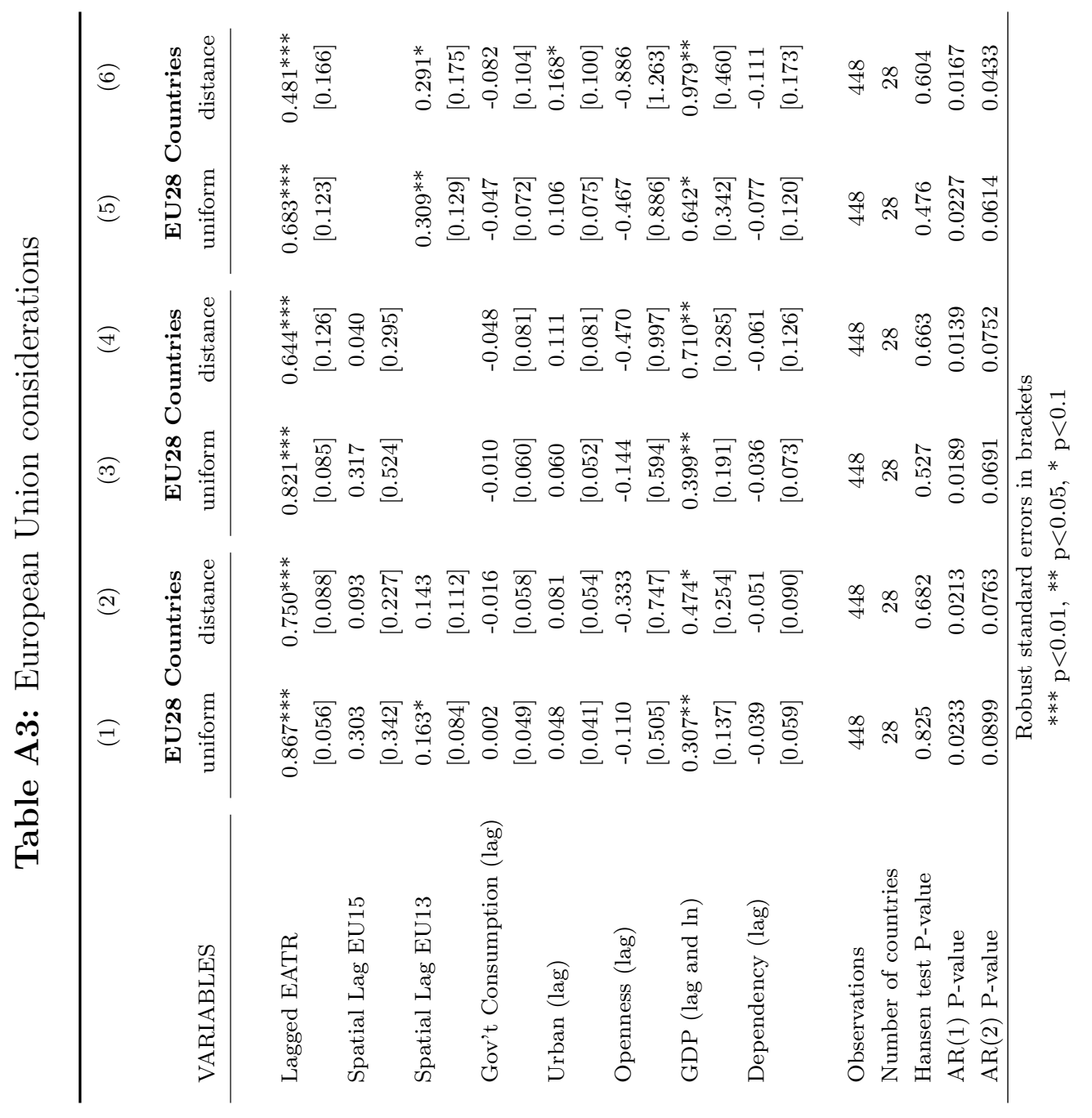




\subsection{Data}

\subsubsection{Computation of EATR}

The concept of Devereux and Griffith $(1998,2003)$ models a hypothetical investment project of a company and allows to compute the tax burden on this investment. ${ }^{21}$ The model allows to include the most relevant tax provisions for corporations of a country. ${ }^{22}$ Nominal corporation tax rates, local taxes on profits and surcharges are included. In addition, real estate, property and net-wealth taxes are considered. The computations also consider the depreciation rules for buildings and machinery and the valuation method for inventories. Overall, the modelled investment is assumed to be financed by a mix of new equity, retained earnings and debt. In case of debt financing the possibility of interest deductability is taken into account. Table A4 states the assumptions with respect to the underlying economic parameters.

Table A4: Assumptions for EATR computation

\begin{tabular}{|c|c|}
\hline Category & Assumption \\
\hline Types of assets & $\begin{array}{l}\text { industrial buildings } \\
\text { tories }(0.22 \%)\end{array}$ \\
\hline Source of finance & $\begin{array}{l}\text { retained earnings }(3: \\
(33.33 \%)\end{array}$ \\
\hline $\begin{array}{l}\text { True economic depreciation (declin- } \\
\text { ing balance) }\end{array}$ & $\begin{array}{l}\text { Buildings: } 3.1 \% \\
\text { Machinery: } 17.5 \%\end{array}$ \\
\hline Lifetime (for tax purposes) & $\begin{array}{l}\text { Buildings: } 25 \text { years } \\
\text { Machinery: } 7 \text { years }\end{array}$ \\
\hline Inflation Rate & $2 \%$ \\
\hline Real interest rate & $5 \%$ \\
\hline Pre-tax rate of return & $20 \%$ \\
\hline
\end{tabular}

$21 \quad$ Please also see European Commission (2001) for explanations and applications of the model.

22 Taxation at the level of the shareholder is not taken into account because it does not affect decisions of corporations when assuming that there is significant international portfolio investment, see e.g. Devereux and Pearson (1995, p. 1660). 


\subsubsection{Control Variables}

Table A5: Descriptive Statistics

\begin{tabular}{llllllll}
\hline Variable & Unit & Mean & $\begin{array}{l}\text { Std. } \\
\text { Dev. }\end{array}$ & Min & Max & Obs. & Source \\
\hline EATR & Percent & 25.8 & 7.7 & 8.3 & 47.9 & 748 & ZEW/Oxford \\
Controls: & & & & & & & \\
$\begin{array}{l}\text { GDP (ln) } \\
\text { Gov't Con- }\end{array}$ & \% of GD in Bill. & 26.2 & 1.7 & 22.3 & 30.3 & 748 & Worldbank \\
$\begin{array}{l}\text { sumption } \\
\text { Urban }\end{array}$ & 18.0 & 4.5 & 5.7 & 29.8 & 748 & Worldbank \\
$\begin{array}{l}\text { Dependency } \\
\text { Openness }\end{array}$ & $\begin{array}{l}\text { Percent } \\
\text { (exports + im- }\end{array}$ & 71.8 & 14.5 & 26.8 & 97.5 & 748 & Worldbank \\
& ports)/GDP & & 0.5 & 0.2 & 3.9 & 748 & Worldbank \\
\hline
\end{tabular}

The control variables have been used in comparable settings:

Government Consumption: Davies and Voget (2008) and Redoano (2014)

Urban: E.g., Devereux et al. (2008) and Davies and Voget (2008)

Dependency: Davies and Voget (2008), Redoano (2014); implicitly in Overesch and Rincke (2011) and Crabbé and Vandenbussche (2008).

GDP: E.g., Egger and Raff (2014). 


\subsubsection{Dataset}

Table A6: Dataset European Countries

\begin{tabular}{ll}
\hline Country & Country \\
\hline Austria & Latvia \\
Belgium & Lithuania \\
Bulgaria & Luxembourg \\
Croatia & UK \\
Cyprus & Malta \\
Czech Republic & Netherlands \\
Denmark & Norway \\
Estonia & Poland \\
Finland & Portugal \\
France & Romania \\
Germany & Slovakia \\
Greece & Slovenia \\
Hungary & Spain \\
Italy & Sweden \\
Ireland & Switzerland \\
& Turkey \\
\hline
\end{tabular}

Table A7: Dataset Non-European Countries

\begin{tabular}{|c|c|}
\hline Country & Country \\
\hline \multicolumn{2}{|c|}{ North America: } \\
\hline USA & Canada \\
\hline \multicolumn{2}{|c|}{ Asia-Pacific: } \\
\hline Australia & Korea \\
\hline New Zealand & Japan \\
\hline China & India \\
\hline \multicolumn{2}{|l|}{ Indonesia } \\
\hline \multicolumn{2}{|c|}{ Latin America: } \\
\hline Mexico & Argentina \\
\hline Brazil & Chile \\
\hline
\end{tabular}




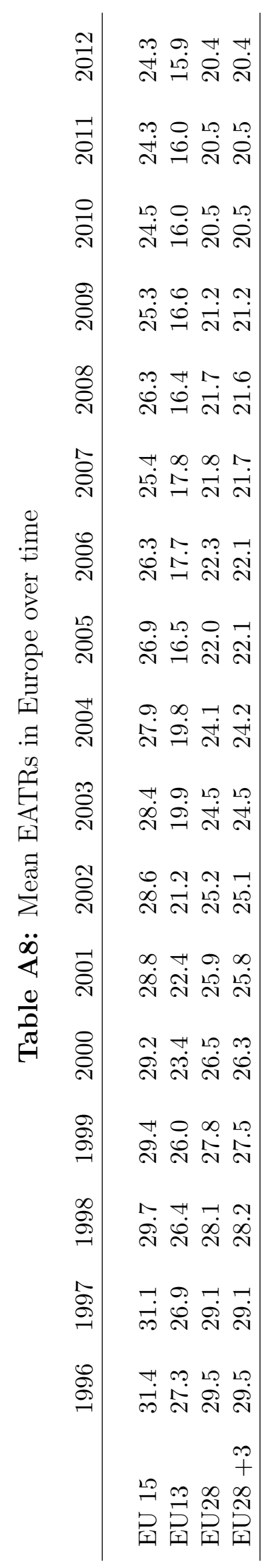

